\title{
Comparative Studies on the Neurosecretory System of Some Species of Voles
}

\author{
Stanisława SIUDA
}

Siuda S., 1978: Comparative studies on the neurosecretory system of some species of voles. Acta theriol., 23, 29: 435-442 [With Plates $\mathrm{XXV}-\mathrm{XXVII]}$.

Studies were carried out on the neurosecretory system secreting vasopressin and oxytocin in three species of the subfamily Microtinae: Microtus agrestis, Clethrionomys glareolus and Pitymys subterraneus. Examination was made of the following: supraoptic nucleus, paraventricular nucleus, eminentia mediana and pars nervosa of the pituitary gland. The studies show that from the morphological aspect the neurosecretory system is most similar in the European pine vole and bank vole, but differs slightly in the field vole.

[Dept. Histol. Embryol., Medical Academy, 15-089 Bialystok, Poland].

\section{INTRODUCTION}

In both vertebrate and invertebrate animals the neurosecretory system consists of a neurosecretory centre, neurosecretory ducts and neurohemal organ. The neurosecretory system in mammals about which most is known is the system secreting vasopressin and oxytocin. The neurosecretory centre of this system consists of supraoptic nucleus and paraventricular nucleus, the neurosecretory ducts are the neurites of these nuclei forming supraoptico-hypophysial tract and paraventricular-hypophysial tract, while pars nervosa of the pituitary gland plays the part of a neurohemal organ (P a w likow ski, 1972). Studies on the neurosecretory system secreting vasopressin and oxytocin are carried out primarily on laboratory animals, and it would therefore appear useful to examine the same systems in wild forms.

The purpose of the present study is to make a comparative examination of the above neurosecretory system in three species of wild mammals.

\section{MATERIAL AND METHODS}

Studies were made on 24 sexually mature males belonging to three species of the subfamily Microtinae: the field vole Microtus agrestis, bank vole Clethrionomys glareolus and European pine vole Pitymys subterraneus, they were obtained from 
the experimental breeding stock of the Mammals Research Institute of the Polish Academy of Sciences at Bialowieża. The animals were killed by decapitation. The encephalon and pituitary gland were fixed in Bouin's fluid as modified by Bock, in order to reveal Gomori-positive neurosecretory material (B o c k, 1966), some of the encephala being fixed in Carnoy's fluid in order to stain the tigroid matter. Paraffin sections were stained hematoxyline-eosine, Gomori's aldehyde fuchsin as modified by Fis cher (1954) and toluidine blue. The diameter of the different cells of the supraoptic nucleus were measured by means of an eyepiece micrometer.

\section{RESULTS}

\subsection{Supraoptic nucleus (NSO)}

Supraoptic nucleus in the field vole is formed of a fairly large number of cells, usually multipolar or bipolar. The neurocytes have round or elliptical cell nuclei. The longer diameter of the cells varies within limits of $14.5-23 \mu \mathrm{m}$, and that of the cell nuclei from $10.5-8 \mu \mathrm{m}$. Three types of cells can be distinguished, depending on neurosecretory contents (Fig. 1, 2-Plate XXV).

Type I - cells with a large amount of granular neurosecretory material occurring in the whole perikaryon. In the field vole they form about $30 \%$ of all $N S O$ cells (Fig. 3 ).

Type II - cells with medium amounts of neurosecretory material. Distinct Gomori-positive granules are situated mainly round the nucleus, forming cone-like concentrations in the direction of the pseudopodium. About $20 \%$ of this type of cell occurs.

Type III - light cells with single granules of neurosecretory material or completely devoid of it - these cell form about $50 \%$. The average amounts of neurosecretory material occur in cell pseudopodia in the form of grains and in greater accumulations form a continuous line. A very large number of neurosecretory cells are situated outside the NSO region along the neurosecretory tract (Fig. 4) among which it is also possible to distinguish three types of cell.

\section{Bank vole (Clethrionomys glareolus)}

NSO cells are multipolar, from $10-15 \mu \mathrm{m}$ in diameter, with cell nucleus diameter of 7.4-9.2 $\mu \mathrm{m}$. It is also possible to distinguish three types of cells in this case (Fig. 5): type I cells containing a very large amount of neurosecretory material and giving the impression of cells homogeneously stained with aldehyde fuchsin (Fig. 6). These cells form approximately $34 \%$, like type II cells, while type III cells form the smallest percentage $(32 \%)$. Large amounts of neurosecretory granules occur in the nerve fibres in the NSO area, running in the direction of 
FM. Neurosecretory cells also occur in individuals of this species along the neurosecretory fibre tract (Fig. 7 - Plate XXVI).

\section{European pine vole (Pitymys subterraneus)}

NSO is formed of a small number of neurosecretory cells from 12.3$-16.7 \mu \mathrm{m}$ in diameter, with nucleus diameter of $7.9-11.4 \mu \mathrm{m}$ (Fig. 8). No type I cells are encountered among them, type II cells forming about $50 \%$, while the remaining cells can be considered as type III (Fig. 9). The nerve fibres contain only negligible amounts of neurosecretory material. Only single cells with a very small amount of neurosecretory granules can be observed along the fibres of the neurosecretory tract.

\subsection{Paraventricular nucleus (NPV)}

The cells paraventricular nucleus are multipolar or biopolar cells. A relatively large amount of neurosecretory material occurs in the neurocytes of $N P V$ in the field vole (Fig. 10), little in the bank vole (Fig. 11) and European pine vole (Fig. 12), the neurocytes being vacuolized in the last two species. In the bank vole in the NPV area the occurrence of fairly regular small Gomori-positive spherules, without distinct connection with cells or their pseudopodia, is striking (Fig. 11).

\subsection{Eminentia mediana (EM)}

$E M$ consists of an ependymal layer composed of one layer of ependymal cells, under which there is the hypendymal layer containing one or two layers of glial cells, this layer being particularly well-developed in the European pine vole. The third layer - a layer of fibres - consists mainly of the nerve fibres of the supraoptic-paraventricular-pituitary tract. In the field vole very abundant granular neurosecretory matter occurs in this layer, often forming conglomerations in the form of homogeneously staining spheres (Fig. 13 - Plate XXVII). In the bank vole this layer almost directly adheres to the ependymal layer (Fig. 14). The smallest amount of neurosecretory granular matter occurs in $E M$ in the European pine vole (Fig. 15). The final layer of EM consists of a palisade layer composed primarily of the pseudopodia of glial and ependymal cells, and a few glial cells between which there are blood vessels. It is devoid of neurosecretory granular matter, although single Gomori-positive grains are sporadically observed in the field and bank voles. This layer is very well developed in the bank vole. The blood vessels originating from the blood vessel network of the portal vein of the pituitary gland, may penetrate as far as the hypendymal layer. 


\subsection{Hypophysis}

Pars nervosa of the hypophysis is formed of glial elements, sinusoidal neurosecretory axon terminals and very numerous blood vessels. In the field vole the very abundant neurosecretory granular matter is distributed evenly over the whole of pars nervosa of the hypophysis in the form of granules, and they most often form large conglomerations appearing as homogeneously staining spheres (Fig. 16). In the bank vole and European pine vole distinct neurosecretory granules surround blood vessels, while neurosecretory matter occurs in a scattered form between glial elements (Fig. 17, 18).

\section{DISCUSSION}

The hypothalamic-hypophysial system in vertebrates has formed the object of a large number of studies under both light and electronic microscopes. Cells which, depending on their morphological appearance and neurosecretory material contents, have been conventionally divided into several types, different authors segregating them in different ways, have been discovered in neurosecretory nuclei. These cells are most often divided into two types - light and dark neurons, with intermediate states (B a chrach, 1957; Kroon, 1963; $\mathrm{Za} \mathrm{mbrano} \& \mathrm{M}$ ordoh, 1966). Z a mbrano \& De Robertis (1966) confirmed that two types of neurons occur in NSO of the rat, also viewed under an electronic microscope.

Some authors distinguish 3 types of neurons, introducing as their third type fusiform cells, with an elongated pycnotic nucleus in which the nucleolus cannot be distinguished, while the cytoplasm of these cells is intensely acidophilic (W a l c z a k \& Ko z i k, 1952; J uris o va, 1973). Many authors consider these cells as degenerating (Ortman n, 1951; Pawlikowski, 1972). Hag en $(1955,1957)$ observed this kind of cell in dogs after pancreatectomy and after injury to the infundibulum, and uses the term "red degeneration".

In the neurosecretory nuclei of the three species of wild animals examined it is possible to distinguish three types of cells on the basis of the amount of neurosecretory granules they contain. No fusiform cells with intensely acidophilic cytoplasm have been found in these animals. The differing amount of neurosecretory granules probably depends on the secretory cycle. Cells staining a light colour are characteristic of the period of considerable physoliogical activity in formation of the secretion and discharge of neurohormones and conversely, dark-staining cells are characteristic of the "calm" period and the start of synthesis (Polenov, 1974). 
The best-developed neurosecretory centres occur in the field vole, in which NSO has the largest and most abundant cells, while the fibre layer of the supraoptic-paraventricular tract in eminentia mediana contains a large amount of neurosecretory material.

E i chner (1965) observed the occurrence in $N P V$ area in the field vole of regular small Gomori-positive spherules. This kind of formation was observed in the bank vole and European pine vole out of the three species studied.

In pars nervosa of the hypophysis in the field vole neurosecretory granules is evenly distributed over the whole gland and is similar to that in the white rat ( $\mathrm{Si} \mathrm{uda} \mathrm{\&} \mathrm{Borowska,1976).} \mathrm{In} \mathrm{the} \mathrm{European}$ pine vole and bank vole neurosecretin in the hypophysis is situated in a characteristic way, mainly surrounding the sinusoidal vessels.

Eminentia mediana in the three species of animals examined is similarly formed to that in the rat ( $\mathrm{G}$ a n o $\mathrm{ng}, 1969)$, except of course for species differences in the breadth of the different layers and also the amount of neurosecretory material contained in it.

The studies made show that differences occur in morphological structure and in neurosecretory material contents in the three species of animals of the subfamily Microtinae. The systems of the European pine vole and bank vole are similar, while the neurosecretory system of the field vole is more similar in respect of its structure to that of the white rat. The difference in neurosecretory granules contents in the animals examined probably depends on the requirements for this hormone by the animal's organism, since it is a known fact that the main physiological role of vasopressin in mammals is water retention, while water is essential to thermoregulating processes ( $\mathrm{Tr} \mathrm{a} \mathrm{c} \mathrm{z} \mathrm{y} \mathrm{k,} \mathrm{1970).} \mathrm{Fluctuations}$ in vasopressin contents in human blood ( $\mathrm{S} \mathrm{z} \mathrm{c} \mathrm{z} \mathrm{e} \mathrm{pańs} \mathrm{k} \mathrm{a} \mathrm{et} \mathrm{al.,} \mathrm{1967;}$ Goodwin et al., 1968) probably constitute the expression of the adaptation of hypothalamus activity to periodically recurring variations in the function of different systems in the organism, primarily in regulation of blood volume.

It is to be anticipated that interesting results could be obtained by carrying out studies on the neurosecretory system of wild animals caught at different times of the year, simultaneously taking into consideration climatical data.

\section{REFERENCES}

1. B a chrach D., 1957: Uber einige Probleme der hypothalamischen Neurosekretion III. Z. Zellforsch. Mikrosk. Anat., 47: 147-157.

2. B ock R., 1966: Uber die Darstellbarkeit neurosekretorischer Substanz mit Chromalaun-Gallocyanin im Supraoptico-hypophysären System beim Hund. Histochemie, 6: $362-369$. 
3. Eichner D., 1965: Uber das neurosekretorische hypothalamisch-hypophysäre System bei Nagern: Erdmaus (Microtus agrestis). Z. Mikrosk. Anat. Forsch., 72: 403-9.

4. Fischer E. R. \& Haskel1 A. E., 1954: Combined Gomori methods for demonstration of pancreatic alpha and beta cells. Am. J. Clin. Pathol., 24: 1433-1434 .

5. Kobayashi H. \& Matsui T., 1969: Fine structure of the median eminence and its functional significante. [In: $»$ Frontiers in neuroendocrinology. Eds. Ganong W. F. \& Martini L.]. Oxford Univ. Press: 3-46. New York, London, Toronto.

6. Goodwin J. C., Jenner F. A. \& Slater S. E., 1968: The diurnal pattern of excretion of antydiuretic hormone. J. Physiol. (Lond.) 196: 112-113 P.

7. Hagen E., 1955: Uber die feinere Histologie einiger Abschnitte des Zwischenhirns und der Neurohypophyse. II Mitt. Acta Anat., 25: 1-33.

8. Ha gen E., 1957: Morphologische Beobachtungen im Hypothalamus und in der Neurohypophyse des Hundes nach Teilläsion des Infundibulum. Acta Anat., 31: $193-219$.

9. J u r i s ov a M. H., 1975: K vaprosu o »tipach" neurosekretornych kletok. Arkhiv Anat. Gistol. Embriol., 65, 8: 45-53.

10. Kroon D. B., 1963: Certain cells the hypothalamic neurosecretory nuclei which are stainable by the acid haematein test for phospholipids according to Baker. Z. Zellforsch. Mikrosk. Anat., 61: 317-337.

11. Ortman R., 1951: Uber experimentelle Veränderungen der Morphologie des Hypophysen-Zwischenhirnsystems und die Beziehung der sog. „Gomorisubstanz« zum Adiuretin. Z. Zellforsch. Mikrosk. Anat., 36: 92-140.

12. Pawlikowski M., 1971: Neurosekrecja i jej znaczenie w regulacji części gruczołowej przysadki. [In: „Ośrodkowa Kontrola Przysadki”. Eds Pawlikowski T., Traczyk W. \& Guzek J. W.]. Państw. Zakł. Wyd. Lek.: 7-13. Warszawa.

13. Pawlikowski M., 1972: Wpływ adrenalektomii i kortykosterydów na jądro nadwzrokowe i część nerwową przysadki szczura. Endokr. Pol., 23: 35-47.

14. Polenov A. E., 1974: O žizniennom puti i sekretornom cykle nejrosekretornych kletok hipotalamusa. Arkhiv Anat. Gistol. Embriol., 66, 7: 5-19.

15. Si d a S. \& B orowska H., 1976: The influence of phoschlor on the supraoptic nucleus in the white rat. Folia Morphol. (Warszawa), 35: 423-428.

16. Szczepańska E., Preibisz J., Drzewiecki K. \& Kozłowski S. 1967: Dobowy rytm zmian poziomu hormonu antydiuretycznego we krwi u ludzi. Pol. Archiwum Med. wewn. 39: 475-481.

17. Traczyk W., 1970: Neurohormony. Państw. Zakł. Wyd. Lek.: 1-101. Warszawa.

18. Wa lczak W. \& Kozik M., 1958: Wplyw diety gnilcorodnej na stan neurosekrecji jąder podwzórza u świnki morskiej. Folia Morphol. (Warszawa), 17, 4: $339-342$.

19. Zambrano D. \& Mordoh J., 1966: Neurosecretory activity in supraoptic nucleus of normal rats. Z. Zellforsch. Mikrosk. Anat., 73: 405-413.

20. Zambrano D. \& De Robertis E., 1966: The secretory cycle of supraoptic neurons in the rat. A structural-functional correlation. Z. Zellforsch. Mikrosk. Anat., $73: 414-431$.

Accepted, March 22, 1978. 
Stanisława SIUDA

\section{BADANIA POROWNAWCZE UKŁADU NEUROSEKRECYJNEGC U NIEKTORYCH GATUNKOW NORNIKOW}

Zbadano układ neurosekrecyjny wydzielający wazopresynę i oksytocynę trrech gatunków podrodziny Microtinae: Microtus agrestis, Clethrionomys glareolus i Pitymys subterraneus. U 24 samców dojrzałych płciowo pochodzących z Białowieskiego Parku Narodowego, badano jądro nadwzrokowe, jądro przykomorowe, wyniosłość pośrodkową oraz część nerwową przysadki mózgowej. W zależności od zawartości neurosekretu stwierdzono występowanie na terenie NSO trzech typów neuronów. Istnieją różnice gatunkowe odnośnie zawartości procentowej poszczególnych typów komórek neurosekrecyjnych jak również grubości poszczególnych warstw wyniosłości pośrodkowej oraz zawartości w niej neurosekretu. Najlepiej rozwinięte ośrodki neurosekrecyjne występują u nornika, u którego NSO posiada największe i bardzo liczne komórki a warstwa włókien drogi nadwzrokowo-przykomorowej w wyniosłości pośrodkowej zawiera dużą ilość neurosekretu. Układ neurosekrecyjny nornika pod względem morfologicznym różni się nieco od układu neurosekrecyjnego darniówki i nornicy. 


\section{EXPLANATION OF PLATES XXV-XXVII}

\section{Plate XXV}

Fig. 1. Nucleus supraopticus of the field vole. Stained with aldehyde fuchshchsin. Magn. $220 \times$.

Fig. 2. Nucleus supraopticus of the field vole, showing 3 types of neurosecretetretory cells. Stained with aldehyde fuchsin. Magn. $480 \times$.

Fig. 3. Nucleus supraopticus of the field vole, showing type I cell. Stained ww with aldehyde fuchsin. Magn. $480 \times$.

Fig. 4. Neurosecretory cells of the field vole outside NSO area. Stained with alalaldehyde fuchsin. Magn. $220 \times$.

Fig. 5. Nucleus supraopticus of the field vole. Stained with aldehyde fuchshchsin Magn. $220 \times$.

Fig. 6. Nucleus supraopticus of the field vole, showing type I cells. Stained wiw with aldehyde fuchsin. Magn. $480 \times$.

\section{Plate XXVI}

Fig. 7. Neurosecretory cells of the field vole situated along the supraoptic ar a and periventricular fibre tract. Stained with aldehyde fuchsin. Magn. $220 \times$.

Fig. 8. Nucleus supraopticus of the European pine vole. Stained with aldehydyhyde fuchsin. Magn. $220 \times$.

Fig. 9. Neurosecretory cells, type II and III, in NSO of European pine vole. Staininined with aldehyde fuchsin. Magn. $480 \times$.

Fig. 10. Nucleus paraventricularis of the field vole. Fairly large amounts of neurururosecretory granules can be seen. Stained with aldehyde fuchsin. Magn. $480 \times$.

Fig. 11. Nucleus paraventricularis of the bank vole. Neurocytes vacuolized ararand almost completely devoid of neurosecretin. Stained with aldehyde fuchsin. Magagagn. $220 \times$.

Fig. 12. Nucleus paraventricularis of the European pine vole. Stained with aldehycyayde fuchsin. Magn. $220 \times$.

\section{Plate XXVII}

Fig. 13. Eminentia mediana of the field vole, showing numerous neurosecretororory granules in the nerve fibre layer. Stained with aldehyde fuchsin. Magn. $220 \times 1 \times 0 \times$.

Fig. 14. Eminentia mediana of the bank vole. Stained with aldehyde fuchsisirsin. Magn. $220 \times$.

Fig. 15. Eminentia mediana of the European pine vole. Stained with aldehyd/dyde fuchsin. Magn. $220 \times$.

Fig 16. Pars nervosa of the hypophysis in the field vole. Stained with aldehydrdyde fuchsin. Magn. $220 \times$.

Fig. 17. Pars nervosa of the hypophysis in the bank vole. Stained with aldehyddede fuchsin. Magn. 220X.

Fig. 18. Pars nervosa of the hypophysis in the European pine vole. Stained wititrith aldehyde fuchsin. Magn. $220 \times$. 


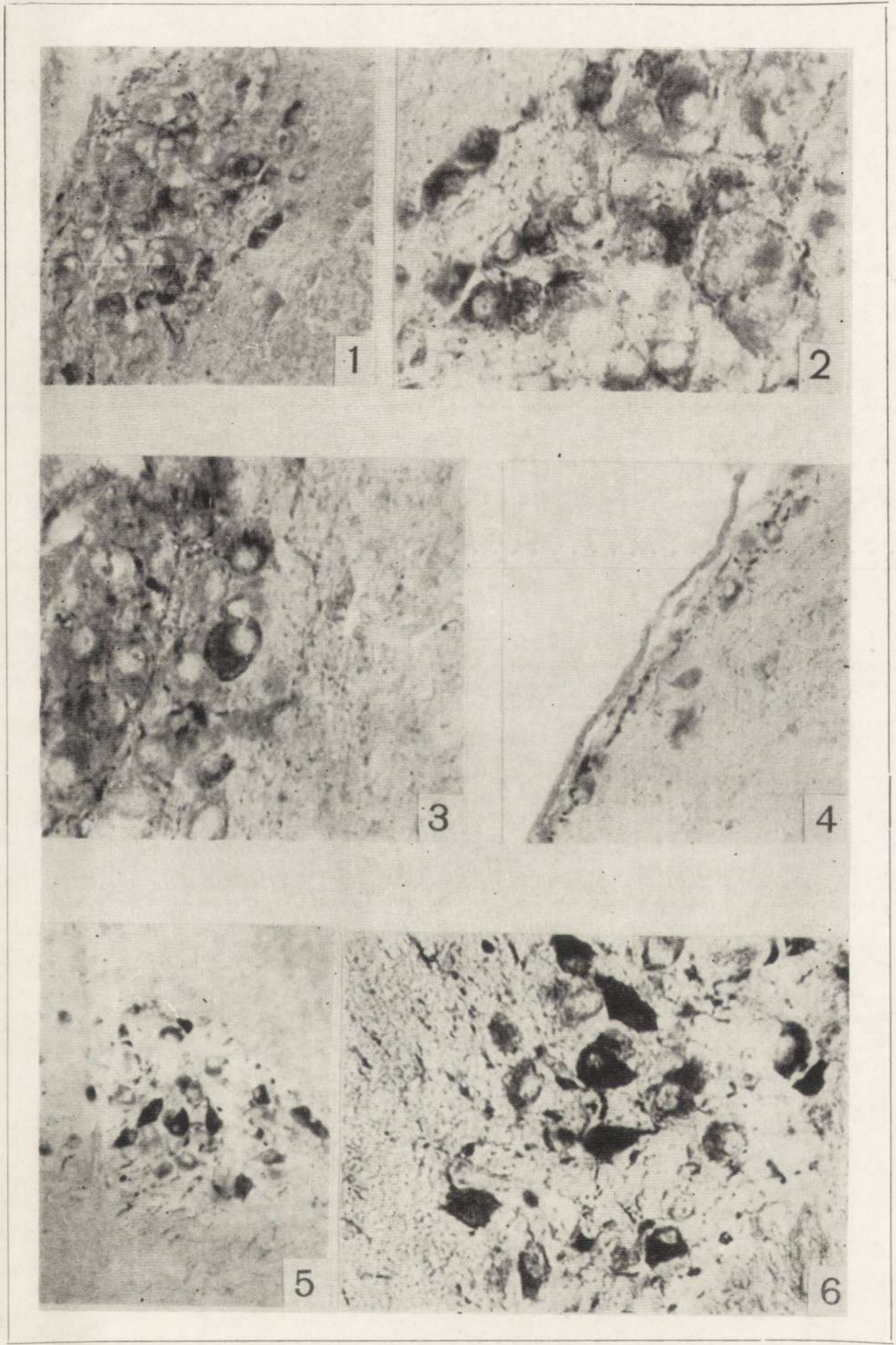




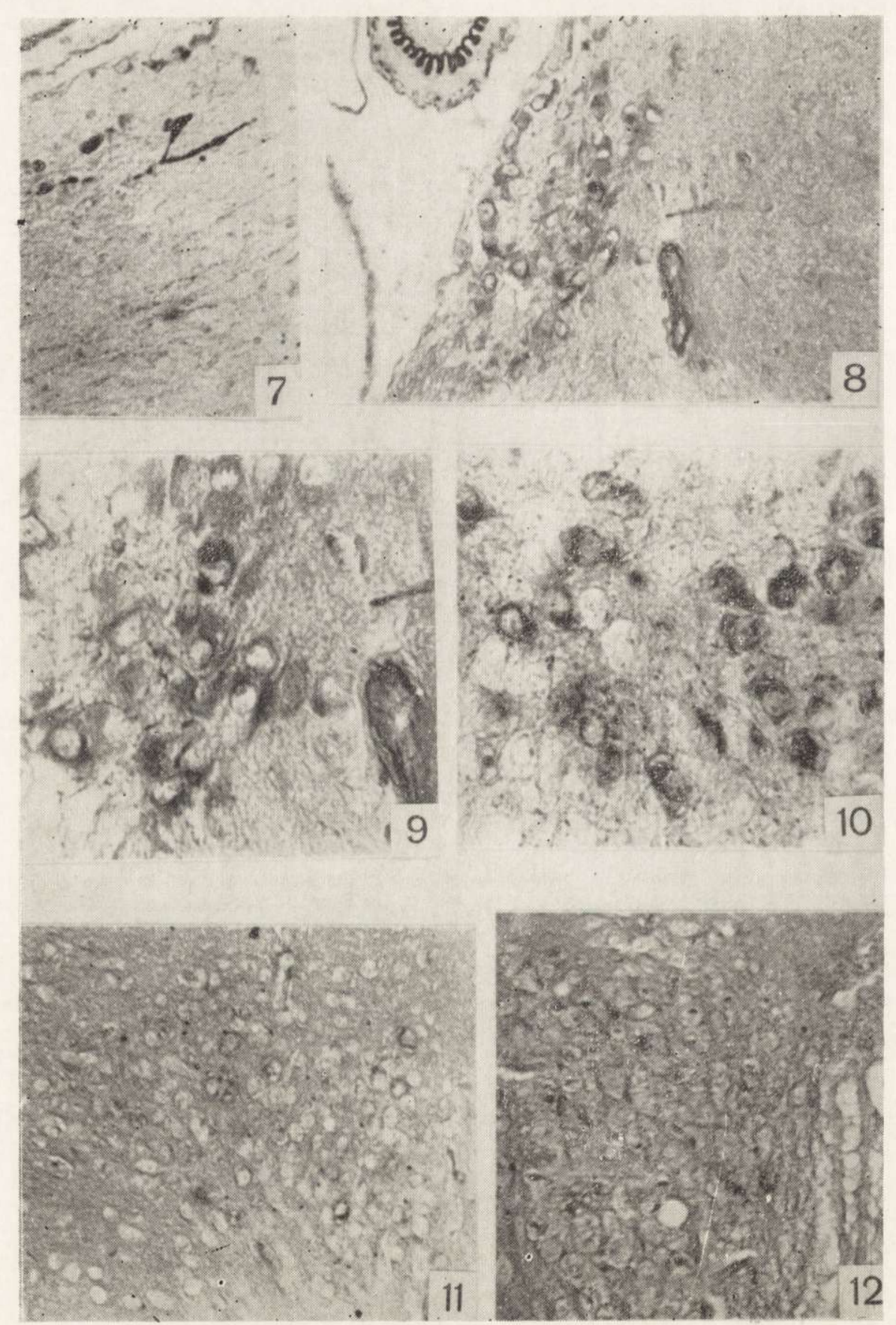




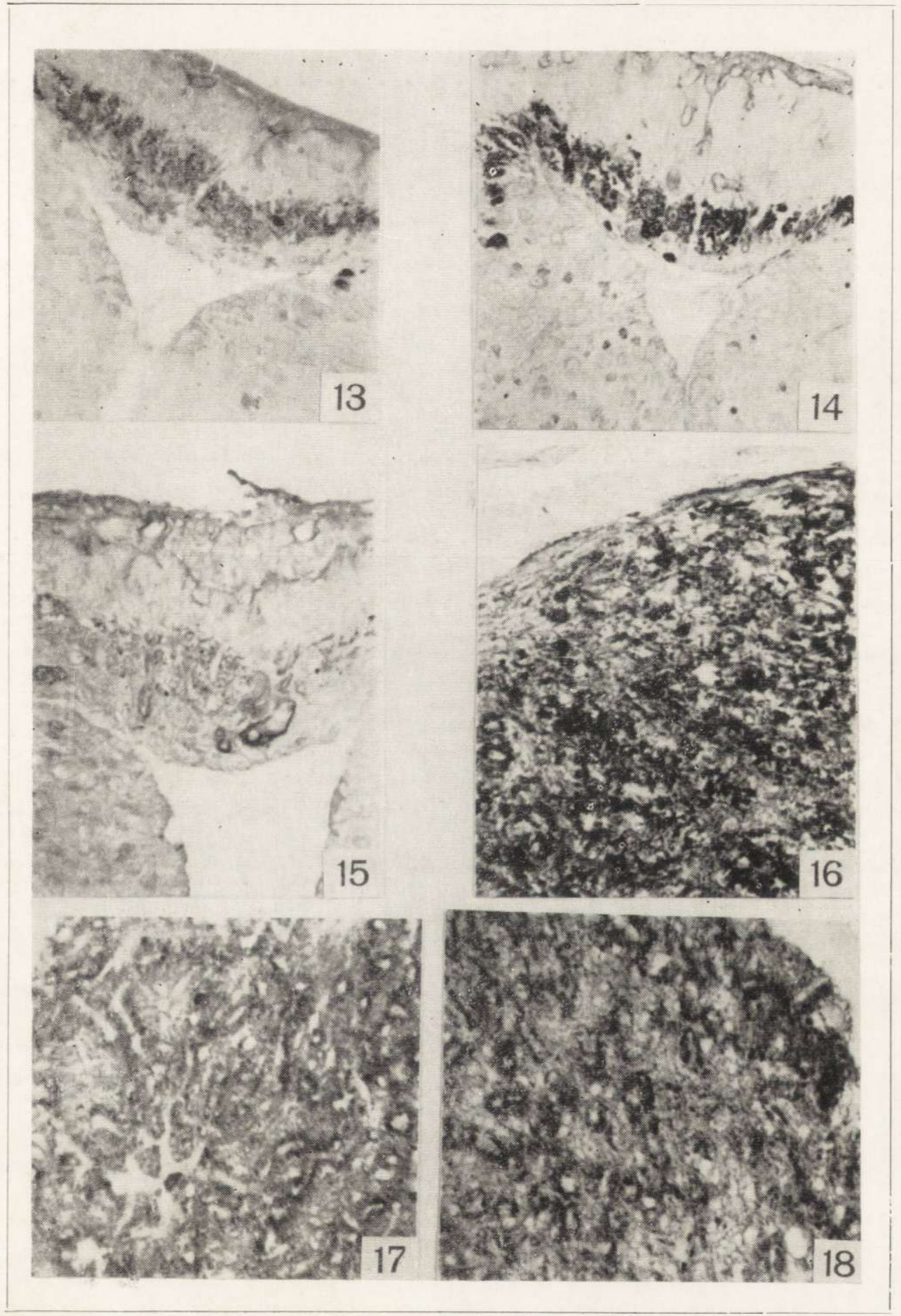

S. Siuda 